\title{
NO SHEEP SACRIFICED IN KAMPUNG NAGA STUDY ON CELEBRATIONS THE EID AL-ADHA AND THE HAJAT SASIH IN KAMPUNG NAGA, TASIKMALAYA
}

\author{
Bambang Misno \\ Al Hidayah State College of Islamic Studies, Bogor
}

\begin{abstract}
People will do their best to apply their religious beliefs in the form of different religious rituals as a means of reconciling themselves to God. Among the rituals is Idhul Adha festivity held by the indigenous people of Kampung Naga. This festival is very interesting as it continues with the ritual of Hajat Sasih as a form of grateful expression to the ancestors of the community of Kampung Naga. The results of this research showed that the practice of Eid al-Adha Celebration was held with great solemnity according to the Islamic teachings, although there are no sheep sacrificed. The attitude of respect for the custom over Idhul Adha celebration has made them prefer the customary ritual in the form of Hajat Sasih to Idhul Adha which is a sunnah. The Hajat Sasih Ritual is carried out after the completion of the Idhul Adha prayer. The ritual is performed in accordance with the procedures carried out by their ancestors by delivering the Pahajat (parcel containing food and produce) to the Punduh and the Lebe a day before the celebration. Meanwhile, the Punduh and the Lebe also gave their pahajat to the Kuwu (village chief) and the Naib (caretaker) of Neglasari Village. The Hajat Sasih is an expression of gratitude to God represented in the form of a visit to the tomb of the ancestor, i.e. Sembah Dalem Eyang Singaparana. In addition, the Hajat Sasih also serves as a special occasion for the people of Kampung Naga to visit each other and expect the blessing from the visit to the grave and from the rice cone that has been prayed upon by the elders of the village.
\end{abstract}

Keywords: Local Islam, Eid al-Adha, Hajat Sasih, Kampung Naga and visiting the grave.

\section{INTRODUCTION}

Human beings are the most perfect creature on Earth, and this is because they have of two elements within them, i.e. the body and the soul. These elements are further refined with the gift of intellect that distinguishes humans from other creatures. With their intellect, humans are capable of developing their potential, meeting all his needs and carrying out their duties as the Caliph of the Earth (khalifatullah fil ardh). Next, humans try to use all of their potential to meet their needs, from the necessity for the body such as food 
and drink, to spiritual needs such as search for peace, harmony, happiness and self-actualization. In reference to the theory of Abraham Maslow, humans have five basic needs: physiological needs, safety, affiliation, self esteem, and development of potential (Jujun, 2001: 264).

Among human's basic spiritual needs is a need for something as a guideline and a means of achieving spiritual satisfaction. That kind of need is religion, especially the need for guidance and guidelines for the happiness of life. That humans have the potential of embracing religion can be seen through the historical and anthropological evidence. Primitive man, to whom the information never came to know God, turns out they believe there is God though limited "imaginary power". The imaginary power results in the belief of the existence of power outside of humans. These beliefs are known as dynamism, animism and polytheism, (Harun, 2010: 4). Carl Gustave Jung argued that religion included things that are already in the natural subconscious thought. Einstein also declared the existence of a variety of psychological aspects that led to the growth of the religion. Similarly, various factors have prompted various human groups to cling to religion. All of that indicates that human beings have the potential for the presence of other forces outside them called God. In other words people have strong potential for believing in God (Harun, 2010: 6).

Upon understanding that religion is part of their lives, humans need to try to apply such beliefs in various religious rituals and religious patterns. So this time we see a man trying to get themselves close to God in various religious rituals. Although there are many religious rituals observed by humans, they have a connection that cannot be separated from the essence of religious rituals. It is all done in an effort to be closer to God, and they believed that the ritual would be a path to happiness and peace in life.

Among the form of religious rituals that have existed since long ago is respect for the ancestors. This ritual is one of the traditional rituals commonly practiced by various ethnic groups in Indonesia, from the western end of Indonesia's Aceh province to the eastern end of Indonesia in Merauke. They have religious rituals in the forms of homage to the ancestors. Such rituals are directed to the tombs of the dead ancestors. The practice to honor ancestors has developed into belief that ancestral spirits have a power that can influence human life (animism).

The Sundanese as one of the ethnic groups in Indonesia also have rituals in honor of the ancestors. This can be from many religious rituals that exist in regions inhabited by the Sundanese, especially in the province of West Java, Banten, parts of Central Java and Jakarta. In Panjalu, Ciamis District, there 
is ritual of Nyangku performed as a form of homage to the ancestors of the Galuh Panjalu Kingdom. In Garut District, there is a Ziarah Makam Karamah (Karamah tomb visit) to visit the tomb of the ancestors of Kampung Dukuh so that their wishes can be achieved. In Bogor and Kuningan Districts, we can find Seren Taun Guru Bumi, a form of gratitude to God. The ritual begins with a pilgrimage to some of the ancestral tombs. In Banten Province there is a community of Bedouins who have the Muja ritual i.e. homage to ancestral sites (Ekadjati, 2009: 63). Similarly, in Indramayu there is Sedekah Bumi ritual, a form of gratitude to God by visiting the graves of their ancestors. Meanwhile, in the indigenous village of Banceu, Subang District, we can find Ngaruat Bumi ritual as a form of homage to the ancestors. Similarly, in Tasikmalaya they have Hajat Sasih practiced by the community Kampung Naga as a ritual to honor the ancestors of Kampung Naga.

When Islam arrived at the land of Pasundan and came into contact with the Sundanese culture, there was a dialog that occurred between the two, a process of complementing between Islam and the Sundanese culture to create a representation of both cultures. This new culture was then passed to the next generations so whether realized or not, the new culture is Islamic culture with a local touch. Among the form of dialog between Islam and the local culture is the celebration of Eid al-Adha followed by the ritual Hajat Sasih practiced by the community Kampung Naga in Tasikmalaya District. The community of Kampung Naga as a sub-culture of the Sundanese accepted Islam as their religion since the founding of the village, so the process of acculturation is not realized by the subsequent generations. Therefore, this research attempts to answer the following questions: what is the process of observing Eid al-Adha and Hajat Sasih in Kampung Naga? Does acculturation occur between Islam and Sundanese custom in this ritual?

\section{KAMPUNG NAGA: HARMONY BETWEEN HUMANS AND THE UNIVERSE}

Kampung Naga is accessible from Bandung through Tasikmalaya and Garut. Through Tasikmalaya, it's a $30 \mathrm{~km}$ trip, through Bandung-Garut-Singaparna route approximately $160 \mathrm{~km}$, while from the town of Garut only $26 \mathrm{~km}$. To find the direction to Kampung Naga, there is a signpost pointing towards the village. Upon entering Kampung Naga, visitors will be greeted by a gate with a roof made from injuk (plant that looks like cowlick) with a height of about 5 meters. To the right of the gate there is a Banyan tree that gives the impression of cool, and according to Mr. Abdul Majid, one of the owners of stalls naot far from the gate, the tree was planted at the same time the parking lot terminal 
of Kampung Naga was constructed. On the left there is a sign that reads "this land belongs to the Government of Tasikmalaya District a land area of 3,218 $\mathrm{m} 2$, certificate number 10 .

Stepping into the terminal (parking lot), there is large area for parking, allowing up to ten large buses to be parked there. On the left there is a building that serves as a place to store drums of kerosene. The buildings next to it are the Information Center, and the office of Kampung Naga Cooperative named "Sauyunan". The building also serves as the Office of the Tour Guides' Association of Kampung Naga abbreviated as "Hipana". Next to this Office, we can find the souvenir stalls selling hand-crafted products of the community of Kampung Naga. Not far from here, there is place for burning trash. Opposite this place, there is an unfinished building used for the parking counter and souvenir store.

At the end of the left side of the parking lot stands the Kujang Pusaka Monument that looks magnificent in dominant black. The monument is surrounded by an iron fence that has a door at the front side. On both sides of the gate were the tiger head statues. To the right of the monument there is a detailed description of the construction project. It reads the monument was inaugurated by the Governor of West Java on April 16, 2009 or 19 Maulud 1430 $\mathrm{AH}$. The initiators of this monument were Anton Charliyan, who at the time served as the Regional Police Chief of Priangan and H. Derajat Hadiningrat as the Head of Graha Limau Kencana. The monument is surrounded by a small pond approximately $80 \mathrm{~cm}$ in diameter, and is surrounded by iron railings, except at the front side. On the back there is a wall that separates the monument from the residents of Sa-naga.

To reach thelocation of Kampung Naga there are several paths that can be taken, but the main access used by the visitors is by climbing down the approximately 400 stairs. I climbed the first 11 stairs to the stairs to reach the junction. From here the trip continues by climbing down more stairs and walking down the street on the bank of the Ciwulan River. The trip to the entrance of the village is filled with a view of the River on the right, and the splash of water from a cliff at the right side brings a different charm of atmosphere. The scenery is a blend of green plants and brown rustic land. From a distance, Kampung Naga can be seen with a neat line of houses in dominant black. The trip down the road of the village on the bank of Ciwulan River is approximately 500 meters and ends in a turn to the left toward Kampung Naga.

Entering the area of Kampung Naga, we can see an open land with two houses on the left and three houses on the right. The Kuncen House sits at the left, the second from the entrance. In addition to the open land, a mosque and the 
Bale Patemon stand side by side. On the left of the mosque, there is the site of a former Leuit lined with welahan bamboo. Walking up the stairs made of stone and turn slightly to the right, we will arrive at the Bumi Ageung. This building is one of four buildings that are sacred and should not be photographed, and not everyone can enter it. Even the residents of Kampung Naga themselves are not allowed to.

On the other side of the Bumi Ageung bounded by a fence, there are residential homes. Next to it, there is another building which is called katarajuan, i.e. a building used by the representatives of Jahiyang village who will join the Sasih ritual. This building is also not allowed to be photographed up close. The trail located on the side of this building is the path to the tomb of Eyang Sembah Dalem Singaparana. At this location, not everyone can enter or take photographs.

\section{SETTLEMENT PATTERN, SOCIAL ORGANIZATION AND RELIGIOUS SYSTEM}

The pattern of settlement in Kampung Naga has a characteristic which cannot be found in other regions. There are three divisions of territory separated and bordered by Jaga Kandang on their respective areas. The first area is used for the bathrooms, (pacilingan), balong, goat stalls, saung lisung, and in the eastern part lies the Ciwulan River with its leuweung karamat. This forest area also is believed to be gross because it is a place for the dedemit and jurig defeated and placed there by the Sembah Dalem. The next area is the area of the settlement, home to residents of Kampung Naga. There are 113 buildings with 108 houses, the rest are the mosque, Bale Patemon, Bumi Angeung, Leuit, and Katarajuan. In this area there is also a large field used for drying grain and a playground for children. In addition to the site of a former mosque there is a leuit which is characterized by round-the-fence made of awi (bamboo), while behind the Kuncen House or opposite the mosque and the Bale Petemon stands a 25 meter Peshalatan or Depok which are also surrounded by a bamboo fence around it without a gate.

The placement of the houses is regulated in such a way in consideration of family values, for example, the houses must face each other so as to promote intensive interaction between the owners especially when they are sitting on the tepas imah. The pattern of the interior of the house that places the kitchen at the front side with a sasag wall also allows the neighbor to find out whether the owner is cooking or not so that they will quickly help them. The see-trough sasag wall will also allow for quick help when a fire or accidents occur in the home. The distance between one house and another is approximately 1 meter, 
while the distance between one house and the opposite more varied, from 1.5 meters to 2.5 meters. All the houses in Kampung Naga are in the form stage like building with a distance from the ground between 60 and $80 \mathrm{~cm}$. This type of house proved to be resistant to earthquakes and free from disturbance of reptiles.

The third Area is where the tombs are located which is considered sacred by the people of Kampung Naga. The location is to the west of the settlement on a small hill with shrubs around and small trees around it. This area is a restricted forest not accessible to anyone (leuweung larangan). This area is also called leuweung karamat because this is where the tomb of Sembah Dalem Eyang Singaparana. In addition, there are also several other tombs of his followers. This area is outside the settlement bordered by kandang jaga and at the front there is a door made of bamboo.

Kampung Naga is located in a lush valley surrounded by rice fields in the north and the south, while to the west there is a hill, and in the eastern part there is a Ciwulan River and a plateau above it. The population is 314 with 108 households. Administratively, Kampung Naga is part of Neglasari Village, Salawu Sub-district, Tasikmalaya District, West Java province. Currently, all the households constitute one neighborhood association (RT) i.e. RT 01 RW 01. According to Mr. Uron, Chairman of the RT in Kampung Naga, "Actually Kampung Naga used to have 4 RT's then reduced into 2 and now merged into one. “

Kampung Naga is led by a Kuncen, i.e. Mr Ade Suherlin. A kuncen has full responsibility for the continuity of custom and culture in Kampung Naga. The office Kuncen itself is obtained through lineage with specific requirements i.e., it must be a male, adult, have mastered the procedures for custom and obtained consent from his ancestors (the Suryani, 2010: 43). In carrying out his everyday responsibilities, a Kuncen assisted by a Lebe and a Punduh. Currently the Lebe is Mr. Ateng Gilani while the Punduh, Mr. Maun. A Punduh has the responsibility to conduct Ngurus Meres Gawe i.e. maintaining the sustainability of the custom and norms in Kampung Naga. He also serves as the keeper of the village when there are guests who violate the restrictions that have become local custom. Meanwhile the Lebe is responsible for the management funeral, marriages and other religious affairs.

In addition to the indigenous leadership, there is also formal leadership of the Government, namely the Chairman of RT (neighborhood association) currently served by Mr. Uron. Among the responsibilities of the Chairman of the RT is being a facilitator/liaison between residents of Kampung Naga and local governments at the Village, Sub-district or District level. In addition, 
Chairman of the RT also socializes the programs created by Government, such as raskin (rice for the poor). In practice the task of Chairman of the RT is always discussed with the elders and Kuncen of Kampung Naga.

The entire community of Kampung Naga is Muslim. Since the beginning of its establishment, Islam has become the religion of their ancestors. Proof of this is a place for prayer that is currently preserved as Peshalatan or Depok. At the time of Hajat Sasih, this place is cleaned as a form of homage to the ancestors who have constructed the venue. Their Islamic faith is also reflected in everyday life by establishing five daily prayers, calling the adhan and praying in congregation in the mosque. The Mosque of Kampung Naga, which is located in the center of the settlement, has become a center of religious activities of the community. It also serves as a place for holding major Islamic celebrations such as the Eid al-Adha prayer, Eid Prayer, Mauludan, Nishfu Sha'baan, Tarawih in Ramadan, and Friday prayer. The Friday prayer is performed with a khatib (sermon giver) coming from the executive board of the mosque considered capable of being a khatib Friday. The mosque also serves as the center of activities during the Hajat Sasih carried out six times a year. On a typical day, the mosque is a place to recite the Qur'an for children of the community of Kampung Naga.

The implementation of the Islamic religion in Kampung Naga does not eliminate the traditions and custom that they have inherited from the ancestors. The beliefs about the various occult things are still common. Similarly, when they receive orders from the ancestors, they will soon put them into practice. If it is a ban, then they certainly will never break it. Some customary rules which survive to this day are the prohibition of entering the restricted forest, the tomb of Sembah Dalem Singaparana, Bumi Ageung and the sacred forest. The places according to their beliefs are sacred and should not be visited by any person. In addition, when sitting or sleeping, one is not allowed to stick his feet toward the west. The prohibitions are called "pamali" which are unwritten rules but understood by the entire community of Kampung Naga. Traditionally, the community Kampung Naga also believed in various spirits who control several places around the village. For example, the existence of the guard of water called jurig cai, kuntilanak, etc. As agricultural society, they also believe in the rice goddess called Nyi Pohaci. As a form of respect to Nyi Pohaci, they have various rules related to rice, for example providing a rujakan in every stage of rice growth in paddy fields to rice storage process in a leuit. In addition, as indigenous peoples in general, they have great respect for their ancestors. Therefore, to honor the ancestors, they perform rituals in the form of pilgrimage to the ancestors' tombs. In Kampung Naga, the ritual of pilgrimage to the tomb of the ancestors called the Hajat Sasih is carried out six times a year. 
To maintain the custom of Kampung Naga, the local people have restrictions to discuss matters relating to custom on Tuesdays, Wednesdays and Saturdays. On the three days mentioned, they are not allowed to discuss indigenous issues; the three days are used for quiet contemplation, introspection and effort to be able to better carry out the custom of the ancestors. On these three days, there are no celebrations or special practices. These days have a very important position so that any event will be postponed or transferred to another day if it coincides with the three days.

\section{CELEBRATION OF EID AL-ADHA AND RITUAL OF HAJAT SASIH}

The atmosphere of the mosque seemed dusky with a kerosene lamp in the center. A man is calling for prayer, and before doing so he hit the kokol and bedug as a sign that the dawn has arrived. Just a few minutes for praying sunnah early morning prayer, the iqamat was then was pronounced. The imam of the prayer was Mr Karmadi, one of the residents of Kampung Naga who is also a close relative of the Kuncen. Several men lined up behind him. This time, no more than ten people performed prayer in congregation at dawn. After a short Dhikr, they shook hands and immediately went back to their respective homes. Kang Entang returned home briefly, changed his prayer outfit, then immediately headed to the balong.

After being left for approximately 1.5 hours, the water in the balong was getting less; the fish began to appear to be searching for deeper water. After a short wait finally Kang Entang made a sort of small trenches to facilitate the catching of fish. After doing some movement to keep the fish gather at a place provided, he began to catch them with a sair. Kang Entang was not alone. He was now assisted by some residents who came to help catch the fish. Pak Ucu, Kang Iin and his son also took down to the balong.

In accordance with the request of the elders, the first fish to catch is the nila (tilapia) fish. With a sair Kang Entang caught some of them and put them into a jerry can with one of the sides cut open. After catching $20 \mathrm{~kg}$ of fish, he immediately took them to the home of indigenous elders to be cooked. The next fish caught were the Nilem. As these fish were available in large quantities, then the selection was done by selecting the ones ready for harvest for the Hajat Sasih. The fish caught weighing $25 \mathrm{~kg}$ and were distributed to the residents of mainly indigenous elders. One day before the Hajat Sasih, the residents of Kampung Naga prepared dishes that would be used in the ritual. Some women looked busy pounding rice flour as an ingredient for making fried foods, while most other mashing the rice for the same purpose. Some residents also helped grinding grain using a machine called ngadisel. 
The men in Kampung Naga also lent a hand. Most of them were engaged in the preparation of Hajat Sasih the following day. Some residents also caught fish fishing in their own balong. Others went to the Ciwulan River for the same purpose. For those who do not like fish, then they chose a chicken dish for the Hajat Sasih. Some chicken was obtained from the market, while some from domesticated livestock called hayam kolong. For practical reasons, some residents chose to buy cooked foods from the kiosks located outside village or waited for the vendors selling foods such as tempe, tofu, and other side dishes.

The preparation for the Hajat Sasih intensified as the sun began to rise. Some women were busy with their household work to prepare for bimonthly celebration of the Hajat Sasih. They looked busy cooking and frying fish, chicken, or peeling potatoes. Before they started cooking, all the cookware was cleaned and prepared. Making tumpeng (rice in corn shape) is the main thing in preparing for the celebration for women. Daon cau (banana leaves) are used for the cover of thr tumpeng. It is the responsibility of the men to collect banana leaves.

One day ahead of the Hajat Sasih, the ritual of pahajat is also done by delivering the atahan to the Punduh and the Lebe. The Atahan itself consists of rice, banana, cassava, yams, and so on, as a form of homage to the elders of Kampung Naga. The tradition of delivering the pahajat has been passed down from generation to generation. In this case if one family gives their pahajat to the Punduh, then they will continue this when the Hajat Sasih comes. Likewise, if a family gives their pahajat the Lebe, then they keep doing so for the next generations to come. The Atahan given by the residents to the Punduh and the Lebe will be used for the purpose of the Hajat Sasih or takbiran nights during the Hajat Sasih which are usually performed in the months of Syawal, Rayagung (Eid al-Adha), and Mulud.

The Punduh and the Lebe have a tradition to give the Pahajat to the Kuwu (village chief) and the Naib. The Punduh will always give his Pahajat Mr. Kuwu (village chief) while Lebe will give his Pahajat to the Naib. The Pahajat given by the residents to the Puduh and the Lebe also includes rice, banana, sweet potato, cassava and other produce. In addition, a live chicken is also added as a complement. The tradition to give Pahajat to the Kuwu and the Naib is as a form of homage and gratitude of the villagers to formal government leaders.

The interviews conducted with the Punduh of Kampung Naga revealed that one of the goals of the Hajat Sasih is giving the Pahajat to the elders and leaders both formal (Kuwu and Naib) as well as non-formal (Punduh and Lebe). Its purpose is a form of homage and obedience of the village residents to the elders who have protected them. The Pahajat is carried out on a voluntary 
basis. In this case, it is not required so that there were residents who did not give away the Pahajat. The granting of the Pahajat can be done a few days or one day before the Hajat Sasih. This tradition has been in practice from generation to generation since long ago, so it will be a shame not to do it. Another preparatory activity for the Hajat Sasih is taking root the Kapirit tree for kuramas and bebersih. It serves as a sort of shampoo used at the time of the Hajat Sasih especially when bathing in the Ciwulan River. This root is taken from the Nagawir of slopes on the river bank of the Ciwulan and several other locations. Later this root will be mixed with honje fruit to be used as traditional shampoo. This time the Hajat Sasih is somewhat different because it coincided with the celebration of the feast of Eid al-Adha. Like other Muslims, the people of Kampung Naga also celebrate the Eid al-Adha. A typical celebration of the Eid al-Adha at Kampung Naga is takbiran in the evening.

When the Sun has set, the call for prayer can be heard from the mosque in the center of the village. Although no speakers are used the call for prayer can heard in the entire Kampung Naga. Some of the men rushed to the mosque wearing the sinjang (sarong) and a headband. The sunset prayer was led by Kang Iin, a representative of the mosque. The mosque itself was a bit different than the usual days; on a typical day it is lit by oil lamps, but this time a petromak (kerosene lamp) was in use, so it was brighter and more cheerful with the presence of the children of the village.

The bustle in the home the citizens could also be seen, because in addition to the preparation of the Hajat Sasih, they also were preparing special dishes for the occasion of takbiran to be carried out this evening to welcome the Eid alAdha feast the following day. The wife of the Punduh was busy cutting green pepper, honje flower, tempe, as well as other vegetables that would be typical gembrung cuisine for the takbiran. This tall elder woman was not alone as she was assisted by her daughter and the wife of the Lebe in preparing for the takbiran of the Eid al-Adha.

The evening prayer just finished when several male residents of Kampung Naga flocked to the mosque. Some of them were wearing black and white shirts, and iket on the the head. Spontaneously, some of the men took terbang gembrung (a kind of hand-held drum) out from the pengimaran (podium), each terbang was fixed by some residents. The Punduh, Lebe and Kuncen were seen sitting at the front row of the mosque, while citizens who were ready to hold the terbang sitting on the right. Kang Entang was seen holding a large terbang leaning on the wall.

"Allah is Great ... Allah is Great... Allah is Great ... " the sound of takbir with a typical Sundanese accent slowly articulated in a melodious manner. Some 
children of Kampung Naga were gathering at the back of the mosque. The solemnity continued into the middle of the night, some typical dish like banana stew, boiled Yam, wajik, and banana cake was served. A puff of smoke from the musicians and audience presents a typical village scene found only once a year on the Eid al-Adha. The time was 11:00 and it was time to serve the eagerly awaited gembrung on the night the Eid al-Adha. The rice was placed on plates made of zinc distributed one by one to all the residents who attended, starting with the Kuncen, the Punduh and the Lebe, and the indigenous leaders. All seemed delighted and enjoyed the meal. It was the beginning of a celebration that would be held until the next day. "Enlivening the night of the Eid is a practice of worship." said Didin, one of the residents of Kampung Naga.

During the time for dawn prayer, toward the Eid al-Adha prayer and the Hajat Sasih, activities were limited to prayer and preparation of core rice and side dish. The dawn prayer at the mosque took place as usual. The prayer was performed with solemnity under dimly lit oil lamps. There were only several men who joined the dawn prayer congregation at the mosque, some others did it at home.

Around 6 a.m., all male residents rushed toward the mosque. There were still not many people. Fog still covered the area of Kampung Naga when the Eid al-Adha prayer started. Mr. Danu acted as the imam and Kang Iin called for prayer. Three women joined the Eid prayer at the back row while others were busy preparing cone rice for the Hajat Sasih. After the prayer, Mr. Danu delivered a sermon wearing a white shirt, tartan sarong and black cap. The sermon was delivered in Arabic and the Sundanese language. People gathering at the mosque were listening attentively even though it was drizzling outside.

When the prayer was completed, people shook hands with the Kuncen, the Punduh, the Lebe and several indigenous elders. Then each of them returned home to prepare for the Hajat Sasih. There were no sacrificial animals. The interviews with the Kuncen revealed that that the absence of livestock slaughtering is due to the residents' low income so that there is nothing to sacrifice. Viewed from the economic perspective, this reason is acceptable since most of the residents of Kampung Naga are farmers with a small income. However, there is a ritual of ngaruwat lembur that sacrifices a goat and it proves the first reason is not true. The absence of a sacrificial animal on the the Eid al-Adha is not without cause. It is a religious pattern of the community of Kampung Naga who steadfastly adhere to their custom.

It was 9 in the morning when the sound of kokol (slit drum) was struck. It was a sign for the start of the Hajat Sasih. People began to rush to the Ciwulan River. Some of them were still wearing full clothes, while some others only 
wearing a sarong without a shirt. All of them are not wearing footwear. The Kuncen and some people carried small containers with them to be used as the leuleuran. The participants of the Hajat Sasih walked to the east toward the Ciwulan River. After coming out of the jaga kandang (village border), they turned left and kept walking along the bank of the river and headed to the place for bebersih and kuramas (shared bath).

Arriving at the riverbank, some residents picked honje fruit. Then each of them formed a group to mash the kepirit root and the honje fruit. There are five groups all together, each mashing the root and mix it with the honje fruit. Then they put the mixture into a pot like container. Before starting the bebersih, the kuncen led a prayer reciting the intention for the bath. Next, each participant took the shampoo and rubeed it in the head and then rinsed it with the water of the Ciwulan. After the kuramas was completed, they took off their clothes and took a dip in the river Ciwulan. Then it was continued with abdas (ablution) and putting on the sinjang (sarong). After the completion of the ritual, everyone was not allowed to put on underwear and footwear. They were also not allowed to use a towel. It did not take a long time to perform the ritual. It took approximately a half hour.

Then each participant returned home to change clothes. The outfit used for the Hajat Sasih consists of three pieces, namely the Totopong (headband), tunic, and sinjang. This outfit is used only for the special event of the Hajat Sasih held six times annually. The totopong (headband) worn in this ritual is differs from one worn on a daily basis. Similarly, the sinjang is worn reaching half calves. The robe has no buttons. There is only a piece of string to tie it together but in reality this is rarely used. The participants let their chest uncovered. A belt made of long white cloth is worn to strengthen the sinjang. They are not allowed to put on any footwear and underwear.

After they were done with the outfit, they were headed to the mosque. They entered the mosque by first washing their feet at a spot located on the left and right side of the mosque. In the mosque, they were waiting for the Punduh, the Lebe and the Kuncen currently asking for permission at the Bumi Ageung. The Kuncen, the Punduh and the Lebe departed to Earth Ageung carrying leumareun. Each of them took the leumareun of their own as well as one belonging to the residents. The Bumi Ageung ritual was conducted the Kuncen, , while the Punduh and the Lebe were waiting outside. The Kuncen was there to recite prayer that essentially contains requests for permission to perform the pilgrimage to the tomb. After the ritual at the Bumi Ageung was completed, the Kuncen, the Punduh and the Lebe went to the tomb. Seeing these elders going to the tomb, the participants of Hajat Sasih immediately followed suit. 
The participants carried sapu nyere (broom) taken from the mosque. These brooms are made of kawung tree bristles and tied into a single bond. The broom is carried on the right shoulder. From the mosque they walked past the Bale Patemon then turned right to a rocky path through the hill and turned left and walked straight toward the south and turned again westward toward the tomb. They were walking hand in hand and lined up one person after another without saying a word. Everything was conducted in solemnity.

The ritual at the tomb began with a request for permission by the Kuncen to Eyang Sembah Dalem. In front of the tomb, the Kuncen rcited the unjukunjuk to inform that the Seuweu-siwi Naga (descendants of Kampung Naga) were gathering there, and delivered the intent and purpose of the Hajat Sasih. The unjuk-unjuk was recited by the Kuncen while facing to the west, toward the tomb. It also means facing toward the qibla. In addition to conveying the intent of pilgrimage, the Kuncen also delivered respect and apology should there any custom be forgotten or violated.

Then all participants were welcome to start cleaning the tomb. They swept, plucked the grass growing around the tomb, cut the wild trees growing in the area of the tomb and threw out all the garbage. It took quite a while to clean up. After they finished, they sat together, while the Kuncen was leading the tawasulan prayer to Eyang Sembah Dalem. After the prayer, each participant performed sungkem by lightly kissing the Kuncen's hand and saying nice words.

About five participants returned to clean the Depok, namely the location of the previous place of prayer (peshalatan) located behind the Kuncen's house or on the front right side of the mosque and Bale Patemon. Since the depok is surrounded by a bamboo fence, the only way to get to it is to use the taroje (ladder). There are two ladders used, i.e. one to go up from the outside and the other to go down on the inside. The process of cleaning up the depok was first by removing the garbage in it, picking off the grass, and the slashing the wild trees growing in the area. The process of cleaning up this place is usually done without saying a word. When finished cleaning, then they approached the rock previously used as the pengimaran and did five to seven times of sungkem and then prayed. Each participant taking part in cleaning up the depok would then do the same thing, namely sungkem (holding palms together and paying respect to the rock. This is done for several times.

It was 12:30 when Friday prayer was completed. With no time to waste, the participants of the Hajat Sasih sat around the mosque with the Kuncen, the Punduh, and the Lebe and their family members. The Kuncen would lead the prayer attended by his 12-year-old son who had accompanied the Kuncen since the Friday prayer. Meanwhile, other participants were sitting down facing the 
south, east, and north, and there were two rows in the middle. They were sitting facing each other with cone rice in front of them. In front of the Kuncen and other elders were tumpeng placed in pots called the rigen and boboko.

Before the ngaduiaan tumpeng began, some of the residents who had yet to perform sungkem to the Kuncen at the tomb were allowed to do so. One by one they approached the Kuncen and kissed his hand. There were no words spoken. Once completed, they returned to where they were.

Meanwhile those carrying tumpeng were allowed to bring it into the mosque through the door. In addition, the four windows located on the left and right side of the mosque were also used to bring in the tumpeng. The atmosphere was quite lively when each woman handed the tumpeng to the participants in the mosque. Kang Entang was also helping the women to move the tumpeng into the the mosque. All seemed happy including Kang Entang who was busy serving them one by one. Most residents entered the mosque and sat at the back to watch the recital of prayer, while others waiting outside, seating around the mosque. They looked serious during the procession of the ngaduaan tumpeng as part of the Hajat Sasih.

After the whole tumpeng went into the mosque and the participants were ready for the Hajat Sasih, a woman called Patunggon handed the leumareun to the Kuncen as a form of service to their leader. The Ngadu'aan Tumpeng started by burning incense and the Kuncen reciting prayer for the well-being of all residents of Kampung Naga. Then it proceeded with greetings and religious advice to all participants. The Kuncen's hands were sometimes brought together (sungkem) and both thumbs put to the front of his mouth. After advice from the Kuncen was completed, the Lebe continued by the reciting a prayer and all participants listening to it said "amen". When the Hajat Sasih is held in month of mulud, at the end of the reading of prayers, each participant takes the tip of the rice cone and laid it on a sheet of banana leaf. The prayer is being read, all participants are holding the tip of the rice cone.

With the completion of the reading of prayers, the Hajat Sasih ritual was completed, and the residents were allowed to take their rice cone respectively. Some people lined up to pass the rice cone to another in a row. The atmosphere was so enjoyable with residents waiting for their tumpeng to take it home. Several people living outside the village of Kampung Naga went home with a happy face. Each participant took their own the tumpeng home, some eaten on the way while the rest bought back home. Kang Entang took the rice home to be enjoyed with his family. "There is a blessing in this kind of rice," said Pak Tatang, one of the residents of Kampung Naga. 


\section{CONCLUSION}

The celebration of the Eid al-Adha ritual followed by the Hajat Sasih in Kampung Naga is a tradition that combines the Islamic law and tradition. The Eid al-Adha prayer with takbiran is Islamic tradition that is well accepted by the community as part of their religion. While the tradition of handing over the Pahajat is a custom prevailing in several communities in Indonesia. For example, in the Baduy community in West Java (Edi S. Eka Djati: 2010), where every year they also give a "tribute" to the ruler of Banten Province. The tradition of Pahajat in Kampung Naga is by presenting agricultural produce to elders, in this case the Punduh and the Lebe. The Punduh and the Lebe themselves will also give pehajat to the local village officials, namely the Kuwu (village chief) and the Naib. The tradition passed down through generations is performed in several kingdoms in Indonesia. Then it can be concluded that the pehajat is a kind of indigenous tradition and a Darigama (obedience to the Government).

Other elements of the indigenous tradition include beating the Kokol (slit drum) at the beginning of the ritual, a symbol of local culture in this regard belonging the Sundanese. In addition to musical instrument, the slit drum serves as a medium of communication for the community. Likewise, the ritual of shared bath in the river of Ciwulan is also found in other Indigenous communities, for example in the Baduy Kanekes in Banten where each ceremony always begins with the bebersih (Edi S. Ekadjati: 2010). In the community of Cigugur Kuningan, they also perform such tradition in their customary ritual. The practice of bebersih in the Ciwulan River is always followed with the ahdats i.e. washing the body of dirt. This is of course an Islamic culture that penetrates into the local culture. While the use of the Kapirit root and the Honje as purifier is local wisdom typical of the Hajat Sasih in Kampung Naga.

The unjuk-unjuk at the Bumi Ageung is a form of homage to the elders. This tradition comes from the custom which originated in a way of paying tribute to the ancestors. It is based on the belief that the ancestors have the right to be asked for permission, especially when performing the Hajat Sasih. The tradition that provides leumaren is a local culture that serves as a form of homage to sanctified places or also to the ancestor. It is also a form of communication and manifestation of human gratitude to God Almighty (Giri, 2002: 15). The core of the Hajat Sasih is performing pilgrimage to the tomb of Eyang Sembah Dalem Singaparna.

The purpose of this pilgrimage is to get blessing to all the residents of Kampung Naga in everyday life. The ritual is marked by request for permission to perform a pilgrimage, then all participants will clean up the tombs. When 
finished, the Kuncen will recite the tawasulan i.e. praying for a favor for all the residents of Kampung Naga. The Islamic law that allows a visit to the tomb is very clear, as mentioned in a Hadith which reads "I (Prophet Muhammad, peace and blessings of Allah be upon him) had ordered you not to visit graves, now visit them because it will remind you of death." Then there is tomb visit tradition in Islam. In fact, a visit to the tomb of the ancestors had been practiced before Islam was present in the land of Pasundan. Belief in the strength of the ancestral has existed since ancient times, so visiting the tomb is a ritual that exists in all Sunda cultures in particular and Indonesia in general. The tawasul tradition is also Islamic namely encouraging a person who is still alive to sincerely worship and devote to to Allah Ta'ala. Tawasul in the name of Allah Ta'ala is allowed in Islam. In the Hajat Sasih, the tawasul is perform for the cemetery dweller i.e. Eyang Sembah Dalem Singaparna as the ancestor and founder of Kampung Naga. Therefore, tawasul exists in Islam, but it turns out that the tradition of making someone (including food) as an intermediary also exists in the Sundanese local culture. They are accustomed to praying through the intermediary of their ancestors, in some cases they ask the ancestors to provide a blessed and prosperous life. Thus it can be concluded that the ritual of visiting the tomb had existed before Islam was present in the land of Sunda. Subsequently, this tradition is mixed with Islamic values, creating a culture of pilgrimage which has roots in local traditions and Islam. The tradition of Murak Tumpeng serves as a symbol of culture understood as the embodiment of the mountain which is the source of life for mankind. The tumpeng is also a manifestation of the high place which according to their belief is in the place of God Almighty (Giri, 2002: 18).

\section{BIBLIOGRAPHY}

Abdul Rozak, 2005, Teologi Kebatinan Sunda, Bandung : PT Kiblat Buku Utama

Ahmad Gibson AlBustomi, "Islam-Sunda Bersahaja di Kampung Naga". Posted on http://sundaislam.wordpress.com/2008/01/12/islam-sunda-bersahaja-di-kampung-naga/

Ahmad Sya, M,dkk. 2008. Sejarah Kampung Naga. Bandung: Dinas Kebudayaan dan Pariwisata Provinsi Jawa Barat Balai Pengembangan Kemitraan dan Pelatihan Tenaga Kepariwisataan.

Beatty, Andrew, 2001, Variasi Agama di Jawa : Suatu Pendekatan Anthropologi, Jakarta : Rajagrafindo Persada.

Connoly, Petter (editor), 2011, Aneka Pendekatan Studi Agama, Yogyakarta : 
LkiS

Creswell, J. W. 1998. Qualitatif Inquiry and Research Design. Sage Publications, Inc: California.

Darsa, Undang A. Dan Edi S. Ekadjati. 2006. Gambaran Kosmologi Sunda. Bandung: PT Kiblat Buku Utama.

Dhavamony, Mariasusai. 1995. Fenomenologi Agama, edisi ke 10. Yogyakarta: Kanisius

Ekadjati, Edi S., 2009. Kebudayaan Sunda: Suatau Pendekatan Sejarah, Jilid 1, Jakarta : Pustaka Jaya.

Fetterman, David M. 2010, Ethnography: step-by-step, London : Sage Publication Inc.

Giri MC, Wahyana, Sajen dan Ritual Orang Jawa, Yogyakarta : Penerbit Narasi

Ihromi, T.O. (editor), 2006, Pokok-pokok Antropologi Budaya, Jakarta : Yayasan Obor Indonesia

Kluckhohn, Clyde. 1942. "Myths and Ritual: A General Theory", dalam Harvard Theological Review, XXXV.

Koentjaraningrat, 1985, Kebudayaan Mentalitas dan Pembanguan, Jakarta : PT Gramedia

Koentjaraningrat, 2002. Pengantar Ilmu Antropologi, Jakarta : PT. Rineka Cipta

Koentjaraningrat, 2007. Sejarah Teori Antropologi I dan II, Jakarta : Penerbit Universitas Indonesia Press.

Lubis, Nina Herlina (ed.). 2003. Sejarah Tatar Sunda, Bandung: Pusat Penelitian Kemasyarakatan dan Kebudayaan Lemlit UNPAD

Mattew B Milles. A Michael Huberman, 2007, Analisis Data Kualitatif, UI Press

Moleong, Lexi J, 2006. Metodologi Penelitian Kualitatif, Bandung : PT. Remaja Rosda karya.

Nasution, Harun, 2010, Islam Ditinjau dari Berbagai Aspeknya, Jakarta: UIPress.

Nugraha, Angga. 2011. Makna Simbol Komunikasi Dalam Upacara Hajat Sasih. Bandung : Fakultas Ilmu Komunikasi Universitas Padjadjaran.

Nur Syam, 2007, Madzhab-madzhab Antropologi. Yogyakarta: LKiS Pelangi Aksara

Nur Syams, 2005, Islam Pesisir, Yogyakarta : LKIS

Pokok-pokok antropologi budaya, Ihromi, 2006. Jakarta: yayasan obor Indonesia.

Purwitasari, Tiwi. 2006. "Pemukiman dan Religi Masyarakat Megalitik: Studi Kasus Masyarakat Kampung Naga, Jawa Barat", dalam Arkeologi dari Lapangan ke Permasalahan. Jakarta: IAAI. 
Saringendyanti, Etty. 2008. Kampung Naga, Tasikmalaya Dalam Mitologi: Upaya Memaknai Warisan Budaya Sunda, Bandung : Laporan Penelitian di Universitas Padjadjaran.

Soekanto, Sarjono, 1990. Sosiologi Suatu Pengantar, Jakarta: Rajawali Pers.

Spradley, James P. 2007, Metode Etnografi, Yogyakarta : Tiara Wacana

Suganda, Her. 2006. Kampung Naga: Mempertahankan Tradisi. Bandung: PT Kiblat Buku Utama

Suprayogo, Imam dan Tobroni, 2001, Metodologi Penelitian Sosial-Agama, Bandung : PT. Remaja Rosda karya.

Suriasumantri, Jujun, 2001, Filsafat Ilmu : Sebuah Pengantar Populer, Jakarta Pustaka Sinar Harapan

Suryani NS, Elis dan Anton Charliyan, 2010. Menguak Tabir Kampung Naga, Tasikmalaya : CV. Danan Jaya.

Yulandita, Lastriyana, 2011. Pola Komunikasi Dalam Pelestarian Kampung Adat Suku Naga. Bandung : Fakultas Ilmu Komunikasi Universitas Padjadjaran. 